\title{
Impact of heat stress and hypercapnia on physiological, hematological, and behavioral profile of Tharparkar and Karan Fries heifers
}

\author{
Priyanka Pandey, O. K. Hooda and Sunil Kumar
}

Animal Physiology Division, ICAR-National Dairy Research Institute, Karnal - 132 001, Haryana, India.

Corresponding author: Priyanka Pandey, e-mail: drpriyankapandey12@gmail.com

Co-authors: OKH: hoodaomkanwar1@gmail.com, SK: dr.sunil8507@gmail.com

Received: 01-06-2017, Accepted: 08-09-2017, Published online: 30-09-2017

doi: 10.14202/vetworld.2017.1149-1155 How to cite this article: Pandey P, Hooda OK, Kumar S (2017) Impact of heat stress and hypercapnia on physiological, hematological, and behavioral profile of Tharparkar and Karan Fries heifers, Veterinary World, 10(9): 1149-1155.

\begin{abstract}
Aim: The present investigation was undertaken to study the impact of heat stress and hypercapnia on physiological, hematological, and behavioral profile of Tharparkar and Karan Fries (KF) heifers.

Materials and Methods: The animals of both the breeds of Tharparkar and KF were exposed at different temperatures and $\mathrm{CO}_{2}$ levels. Exposure conditions of $25^{\circ} \mathrm{C}, 400 \mathrm{ppm} \mathrm{CO}$ level, and $60 \%$ relative humidity $(\mathrm{RH})$ were taken as a control condition. The exposure conditions $40^{\circ} \mathrm{C}$ with two levels of $\mathrm{CO}_{2} 500 \mathrm{ppm}$ and $600 \mathrm{ppm}$ with $\mathrm{RH} 55 \pm 5 \%$ and exposure conditions $42^{\circ} \mathrm{C}$ with two levels of $\mathrm{CO}_{2} 500 \mathrm{ppm}$ and $600 \mathrm{ppm}$ with $\mathrm{RH} 55 \pm 5 \%$ were taken as treatments. The exposure period in each condition was $4 \mathrm{~h}$ daily for 5 consecutive days.

Results: Physiological responses (respiration rate [RR], pulse rate [PR], and rectal temperature [RT]) were significantly $(\mathrm{p}<0.01)$ higher and different during all exposure conditions compared to control condition in both the breeds of cattle. KF heifers had higher RR, PR, and RT than Tharparkar heifers. Hematological parameters, namely, red blood cell, hemoglobin, and packed cell volume were significantly higher and different during all exposure condition than control in both the breeds, whereas no significant changes were observed in total leukocyte count and differential leukocyte count. Blood pH increased with increase in temperature and $\mathrm{CO}_{2}$ levels and was significantly higher than control conditions. $\mathrm{PCO}_{2}$ and base excess were significantly $(\mathrm{p}<0.05)$ lower, and $\mathrm{PO}_{2}$ was higher during different exposure conditions than control in both breeds. Restlessness and excitement signs were observed in all the exposure conditions as compared to control condition in both the breeds.
\end{abstract}

Conclusion: Changes in physiological responses, behavioral pattern, and hematological parameters reflect the current functional status of the body system, and it can be used as an index for assessing the adaptation capacity of cattle to predict changes occurring in climate variables due to increasing $\mathrm{CO}_{2}$ levels and environmental temperature.

Keywords: behavior, hematological, hypercapnia, hyperthermia, Tharparkar.

\section{Introduction}

Climate change impacts on livestock are being witnessed all over the world, but its effects are more intense in Indian condition. Evidence from the Intergovernmental Panel on Climate Change [1] is now overwhelmingly convincing that climate change is real and it will become worse and the poorest will be affected more. Warming of global climate has multifaceted effects. Scientists have envisioned that increase in average global temperature above $1{ }^{\circ} \mathrm{C}$ may be beyond the bearable limit of the present-day societies. Hot environment impairs production, reproduction, immune response, metabolic, and health status of livestock. Since the crossbred cattle are more sensitive to temperature rise than indigenous cattle, a rise of $2-6^{\circ} \mathrm{C}$ due to global warming will have more

Copyright: Pandey, et al. Open Access. This article is distributed under the terms of the Creative Commons Attribution 4.0 International License (http://creativecommons.org/licenses/ by/4.0/), which permits unrestricted use, distribution, and reproduction in any medium, provided you give appropriate credit to the original author(s) and the source, provide a link to the Creative Commons license, and indicate if changes were made. The Creative Commons Public Domain Dedication waiver (http:// creativecommons.org/publicdomain/zero/1.0/) applies to the data made available in this article, unless otherwise stated. impact on growth, puberty, and maturity of crossbred cattle, and the negative effects of heat stress will become even more apparent in the future if climate change continues as predicted [2].

$\mathrm{CO}_{2}$ is an asphyxiant gas, the physiological effects of acute $\mathrm{CO}_{2}$ exposure are grouped together under the term hypercapnia, a subset of asphyxiation where breathing is too slow or shallow and causes respiratory acidosis while breathing too fast to the level of hyperventilation causes respiratory alkalosis. Blood performs a number of functions in the body, and any change in its constituents reflects the current functional status of the body system. Thus, the blood constituents can be used as an index for assessing the adaptation capacity of cattle to climate. McManus et al. [3] reported a strong positive correlation between packed cell volume (PCV) and hemoglobin ( $\mathrm{Hb})$ concentration indicating the significance of these parameters for heat tolerance in Brazilian sheep. No significant changes were observed in total leukocyte count (TLC) and total erythrocyte count (TEC) in Sahiwal and Karan Fries (KF) cattle exposed at $40^{\circ} \mathrm{C}$ and $45^{\circ} \mathrm{C}$, but lymphocyte counts decreased, and neutrophil counts increased [4]. Bhan et al. [5] observed an 
increase in the mean TLC values when buffalo heifers were exposed to $42 \pm 1^{\circ} \mathrm{C}$ for $3 \mathrm{~h}$ in a climatic chamber. Insufficient ventilation, especially high $\mathrm{CO}_{2}$ to $\mathrm{O}_{2}$ ratio of animal's house, stimulated respiration and circulation functions of animals [6]. Kadzere et al. [7] reported that $\mathrm{PCO}_{2}>40 \mathrm{mmHg}$ stimulates respiration, whereas lower $\mathrm{PCO}_{2}$ inhibits it. This is because thermally induced hyperventilation decreases $\mathrm{PCO}_{2}$ [8].

The interactive effects of elevated $\mathrm{CO}_{2}$ and temperature stress under environmentally realistic scenarios of global climate change are not well understood in bovines, thereby hampering our ability to predict the consequences of global climate change on bovine physiology. In this study, the short-term exposure (5 days) of Tharparkar and KF heifers at different temperatures and $\mathrm{CO}_{2}$ levels corresponding to the present-day conditions and the predicted future changes in global climate change has been reported.

\section{Materials and Methods}

\section{Ethical approval}

Experiment was approved by the Institutional Animal Ethics Committee constituted as per the article no. 13 of the CPCSEA rules, laid down by Government of India.

\section{Study area}

The National Dairy Research Institute (NDRI), Karnal, is situated at an altitude of 250 meter above mean sea level. Latitude and longitude positions being $29^{\circ} 42^{\prime \prime} \mathrm{N}$ and $79^{\circ} 54^{\prime \prime} \mathrm{E}$, respectively.

\section{Experimental animals}

Twelve apparently healthy heifers, six each of Tharparkar and KF varying from 1 to 2 years of age and average body weight of $196 \pm 3.05$ and $196.16 \pm 2.21 \mathrm{~kg}$, respectively, were taken from the NDRI, Karnal. The experimental animals were maintained and fed as per the standard practice followed at the herd of the NDRI, Karnal. The animals were offered a ration consisting of concentrate mixture and roughages (berseem, maize, or jowar as per the availability at the farm). Concentrate mixture (crude protein $19.81 \%$ and total digestible nutrients $70 \%$ ) contained maize $33 \%$, groundnut cake (oiled) $21 \%$, mustard oil cake (oiled) $12 \%$, wheat bran $20 \%$, de oiled rice bran $11 \%$, mineral mixture $2 \%$, and common salt $1 \%$. Fresh tap water was made available for drinking throughout the time to all the animals throughout the experiment.

\section{Experimental protocol}

a. Animals of both breeds were exposed in a climatic chamber at temperature $25^{\circ} \mathrm{C}, \mathrm{CO}_{2}$ level $400 \mathrm{ppm}$, and relative humidity (RH) $60 \% 4 \mathrm{~h}$ daily for 5 consecutive days and served as control.

b. Animals of both breeds were exposed in a climatic chamber at temperature $40^{\circ} \mathrm{C}, \mathrm{CO}_{2}$ level $500 \mathrm{ppm}$, and RH $55 \pm 5 \% 4 \mathrm{~h}$ daily for 5 consecutive days. After 14 days rest, all the animals were again exposed at temperature $40^{\circ} \mathrm{C}, \mathrm{CO}_{2}$ level $600 \mathrm{ppm}$, and RH $55 \pm 5 \% 4 \mathrm{~h}$ daily for 5 consecutive days. c. After 21 days rest, the animals of both breeds were exposed at temperature $42^{\circ} \mathrm{C}, \mathrm{CO}_{2}$ levels 500 and $600 \mathrm{ppm}$, and RH $55 \pm 5 \%$ in the same way as in B.

\section{Recording of physiological responses}

Physiological responses (respiration rate [RR], pulse rate $[\mathrm{PR}]$, and rectal temperature $[\mathrm{RT}]$ ) were recorded before exposure and at the end of $5^{\text {th }}$ day experiment, and for these routine methods were followed. Animal behavior was recorded by the CCTV camera during the exposure period.

\section{Collection of blood samples}

Blood samples from each animal were taken from jugular vein in heparin-coated vacutainer tubes before exposure and at the end of $5^{\text {th }}$ day exposure in all exposure conditions. From this, approximately $1.0 \mathrm{ml}$ of blood of each animal was withdrawn in a $1.0 \mathrm{ml}$ syringe, and the syringe was made an airtight so that no air can enter into the syringe. This portion of blood was used immediately for blood gas analysis and base excess (BE) determination in Nova Biochemical blood gas analyzer and blood hematological studies in BC-2800 vet blood autoanalyzer.

\section{Statistical analysis}

Data were analyzed using one-way analysis of variance by Statistical Analysis System [9] Software Program, version 9.1, and the results were expressed as a mean \pm standard error and considered statistically significant at $1 \%$ and $5 \%$ level.

\section{Results and Discussion}

\section{Physiological responses}

The mean values of physiological responses, i.e., RR, PR, and RT of Tharparkar and KF heifers during control as well as different exposure conditions are given in Table-1. The RR, PR, and RT of both breeds were significantly higher $(\mathrm{p}<0.01)$ at $40^{\circ} \mathrm{C}, 500$ and $600 \mathrm{ppm} \mathrm{CO}_{2} ; 42^{\circ} \mathrm{C}, 500$ and $600 \mathrm{ppm}$ $\mathrm{CO}_{2}$ compared to control conditions, and the increase in these parameters was more in KF than Tharparkar.

Increased RR is the first reaction when animals are exposed to an environmental temperature above thermoneutral zone. The significance of this increased $\mathrm{RR}$ under heat stress is that it enables the animals to dissipate the excess of the body heat by respiratory evaporative cooling through the expired air, which accounts for $30 \%$ of the total heat dissipation from the body [10]. Davinder [11] reported significantly $(p<0.01)$ higher RR in KF and Murrah calves during summer than winter season. Similar results were reported by Indu [12] in Tharparkar and KF calves when the calves were exposed at $44^{\circ} \mathrm{C}$ for $4 \mathrm{~h}$ in a climatic chamber. Das et al. [13] reported that air temperatures above $20-25^{\circ} \mathrm{C}$ in temperate climate and $25-37^{\circ} \mathrm{C}$ in a tropical climate such as in India, enhance heat gain beyond that lost from the body and induce HS which results into increased body surface temperature, RR, heart rate, and RT which leads to decrease in feed intake, production, and reproductive efficiency 
Table-1: Effect of elevated temperature and $\mathrm{CO}_{2}$ levels on physiological responses of Tharparkar and Karan Fries heifers.

\begin{tabular}{|c|c|c|c|c|c|c|}
\hline \multirow[t]{3}{*}{ Parameter } & \multirow[t]{3}{*}{ Breed } & \multirow{3}{*}{$\frac{\frac{25^{\circ} \mathrm{C}(\text { control })}{\mathrm{CO}_{2} \text { levels }(\mathrm{ppm})}}{400}$} & \multirow{2}{*}{\multicolumn{2}{|c|}{$\begin{array}{l}40^{\circ} \mathrm{C} \\
\text { evels (ppm) }\end{array}$}} & \multirow{2}{*}{\multicolumn{2}{|c|}{$\begin{array}{c}42^{\circ} \mathrm{C} \\
\mathrm{CO}_{2} \text { levels }(\mathrm{ppm})\end{array}$}} \\
\hline & & & & & & \\
\hline & & & 500 & 600 & 500 & 600 \\
\hline \multirow[t]{2}{*}{ RR (breaths/min) } & Tharparkar & $22.66^{\mathrm{Ae}} \pm 0.42$ & $60.66^{\mathrm{Bd}} \pm 0.33$ & $64.83^{B C} \pm 0.73$ & $67.08^{\mathrm{Bb}} \pm 0.60$ & $69.25^{\mathrm{Ba}} \pm 0.52$ \\
\hline & Fries & $23.83^{\mathrm{Ae}} \pm 0.60$ & $78.0^{\mathrm{Ad}} \pm 0.73$ & $81.33^{A C} \pm 0.55$ & $86.0^{\mathrm{Ab}} \pm 0.85$ & $90.16^{\mathrm{Aa}} \pm 0.47$ \\
\hline \multirow[t]{2}{*}{ PR (beats/min) } & Tharparkar & $68.16^{\mathrm{Ad}} \pm 0.30$ & $74.16^{\mathrm{BC}} \pm 0.87$ & $77.0^{\mathrm{Bb}} \pm 0.81$ & $78.5^{\mathrm{Bb}} \pm 0.42$ & $82.0^{\mathrm{Ba}} \pm 0.73$ \\
\hline & Karan Fries & $69.83^{\mathrm{Ad}} \pm 0.60$ & $77.16^{A C} \pm 0.60$ & $79.5^{A C} \pm 0.76$ & $82.5^{\mathrm{Ab}} \pm 0.76$ & $86.16^{\mathrm{Aa}} \pm 0.40$ \\
\hline \multirow[t]{2}{*}{$\mathrm{RT}\left({ }^{\circ} \mathrm{F}\right)$} & Tharparkar & $100.8^{\mathrm{Ad}} \pm 0.26$ & $102.48^{\mathrm{AC}} \pm 0.12$ & $102.86^{\mathrm{Bcb}} \pm 0.16$ & $103.30^{\mathrm{Bb}} \pm 0.20$ & $104.38^{\mathrm{Ba}} \pm 0.16$ \\
\hline & Karan Fries & $101.2^{\mathrm{Ad}} \pm 0.20$ & $102.80^{A C} \pm 0.16$ & $103.58^{\mathrm{Ab}} \pm 0.20$ & $104.21^{\mathrm{Ab}} \pm 0.07$ & $105.68^{\mathrm{Aa}} \pm 0.15$ \\
\hline
\end{tabular}

Mean with different superscripts ( $A$ and $B$ ) in column differs significantly between the breeds for respective parameter for each exposure condition. Mean with different superscripts ( $a, b, c$, d, and e) in the same row differs significantly for respective breed for each exposure condition. $\mathrm{RR}=$ Respiration rate, $\mathrm{PR}=$ Pulse rate, $\mathrm{RT}=$ Rectal temperature

of animals. Similar findings were reported in Holstein Friesian and Brown Swiss cattle when cows were exposed to $0.45 \%$ of $\mathrm{CO}_{2}$ level [6]. The differences in RR were nonsignificant at control condition, but at all other exposure conditions, the RR of KF calves was significantly higher than Tharparkar. It might be due to low heat tolerance of KF compared to Tharparkar. The findings of the present study are also in support of those reported by Singh and Upadhyay [14] who also observed higher RR in KF than Sahiwal cattle during heat stress.

Hooda and Upadhyay [15] reported that the pulse rate reflects primarily the homeostasis of circulation along with the general metabolic status. The observed accelerated PR could be due to the redistribution of blood to peripheral tissues to give a chance for more heat to be lost by sensible and insensible means during exercise and exposure to heat stress. Mohr et al. [16] reported that the mean resting PR of healthy animals increased from $105 \pm 11.1$ to $114 \pm 12.5$ bpm under the influence of external stress and sickness. On increasing the $\mathrm{CO}_{2}$ levels from 400 to 500 and $600 \mathrm{ppm}$, there was a significant increase in PR in both the breeds. Similar findings were reported in Holstein Friesian and Brown Swiss cattle which were exposed to $0.45 \%$ of $\mathrm{CO}_{2}$ level [6]. The authors suggested that a high $\mathrm{CO}_{2}$ level stimulates the circulatory function of the animal which might have resulted in increased PR of the animals. Sagsoz et al. [17] also observed increased PR of Holstein Friesian and Brown Swiss cattle from 65.9 to 69.4 and 61.8 to 62.4 beats/minute, respectively, when the cows were exposed to $522.9 \mathrm{ppm}$ of $\mathrm{CO}_{2}$ level, $21^{\circ} \mathrm{C}$ temperature, and $82 \%$ RH. PR was significantly higher in KF compared to Tharparkar cattle in all the exposure conditions which might be an acclimation process to dissipate extra heat by this breed. Gaughan et al. [18] reported that there was a greater engagement of breeds for heat loss mechanisms which are less adapted to a climate. Aggarwal and Upadhyay [19] also observed similar changes in PR and reported that PR increased from 61 to 79 and 67 to 86 beats/minute in Sahiwal and crossbred cattle, respectively, after $4 \mathrm{~h}$ of solar radiation exposure.
Silanikove [20] stated that RT is an indicator of thermal balance and may be effective in quantifying the discomfort level of the animals during thermal stress. Moran [21] reported that RT of buffaloes was easily influenced by their surrounding temperature, and it increased rapidly during exposures in a hot climate. Chandra et al. [22] reported that RT of KF remained significantly high compared to Sahiwal and Tharparkar cattle during different seasons and the magnitude of increase in RT was higher in KF than Sahiwal and Tharparkar during summer season. Randhawa et al. [23] reported that the temperature humidity index (THI) describes the effect of environment on animal's ability to dissipate heat. During drought, the ambient temperature and RH frequently exceed the critical comfort level of THI (72), resulting in elevated body temperature and panting. In this study, RT was significantly higher in KF compared to Tharparkar at different conditions of elevated temperature and $\mathrm{CO}_{2}$ levels. The higher RT in Bos taurus than in Bos indicus cattle and attributed it to notable differences among different breeds of cattle in their ability to regulate RT. Hansen [24] also stated that zebu cattle are better in the regulation of their body temperature than those of B. taurus cattle of European origin in response to heat stress. RT was significantly different and higher at elevated $\mathrm{CO}_{2}$ levels and high exposure temperatures in both the breeds. It has been observed that, at elevated $\mathrm{CO}_{2}$ levels, the condition of hypoxia is generated and acute hypoxia causes a reduction in body temperature. However, in this study, there was an increase in RT which might be due to high temperature and interactive effects of elevated $\mathrm{CO}_{2}$ level in different exposure conditions.

\section{Hematological parameter}

The mean values of red blood cell (RBC), hematocrit, and $\mathrm{Hb}$ concentration in Tharparkar and $\mathrm{KF}$ heifers are given in Table-2. The concentration of TEC hematocrit and $\mathrm{Hb}$ in both breeds increased with increase in temperature and $\mathrm{CO}_{2}$ levels, and the values were significantly different at different exposure conditions. Between the breeds, RBC, hematocrit, and $\mathrm{Hb}$ were significantly higher in $\mathrm{KF}$ than Tharparkar at 
Table-2: Effect of elevated temperature and $\mathrm{CO}_{2}$ levels on blood parameters of Tharparkar and Karan Fries heifers.

\begin{tabular}{|c|c|c|c|c|c|c|}
\hline \multirow[t]{3}{*}{ Parameter } & \multirow[t]{3}{*}{ Breed } & \multirow{3}{*}{$\begin{array}{c}\frac{25^{\circ} \mathrm{C} \text { (control) }}{\mathrm{CO}_{2} \text { levels (ppm) }} \\
400\end{array}$} & \multirow{2}{*}{\multicolumn{2}{|c|}{$\begin{array}{c}40^{\circ} \mathrm{C} \\
\mathrm{CO}_{2} \text { levels }(\mathrm{ppm})\end{array}$}} & \multirow{2}{*}{\multicolumn{2}{|c|}{$\begin{array}{c}42^{\circ} \mathrm{C} \\
\mathrm{CO}_{2} \text { levels }(\mathrm{ppm})\end{array}$}} \\
\hline & & & & & & \\
\hline & & & 500 & 600 & 500 & 600 \\
\hline \multirow[t]{2}{*}{ Red blood cells $\left(\times 10^{6} / \mu \mathrm{l}\right)$} & Tharparkar & $7.23^{\mathrm{Ad}} \pm 0.18$ & $7.9^{\mathrm{Adc}} \pm 0.22$ & $8.53^{\mathrm{Bbc}} \pm 0.17$ & $8.8^{\mathrm{Bba}} \pm 0.18$ & $9.6^{\mathrm{Ba}} \pm 0.17$ \\
\hline & Fries & $7.58^{\mathrm{Ae}} \pm 0.08$ & $8.3^{\mathrm{Ad}} \pm 0.12$ & $9.16^{\mathrm{AC}} \pm 0.16$ & $9.9^{\mathrm{Ab}} \pm 0.19$ & $10.62^{\mathrm{Ba}} \pm 0.19$ \\
\hline \multirow[t]{2}{*}{ Hemoglobin $(\mathrm{g} / \mathrm{dl})$} & Tharparkar & $9.1^{\mathrm{Ae}} \pm 0.14$ & $10.46^{\mathrm{Bd}} \pm 0.13$ & $11.18^{\mathrm{Bc}} \pm 0.05$ & $12.3^{\mathrm{Bb}} \pm 0.13$ & $13.26^{\mathrm{Ba}} \pm 0.09$ \\
\hline & Karan Fries & $9.4^{\mathrm{Ae}} \pm 0.16$ & $10.85^{\mathrm{Ad}} \pm 0.11$ & $11.80^{A C} \pm 0.10$ & $12.83^{\mathrm{Ab}} \pm 0.10$ & $14.33^{\mathrm{Aa}} \pm 0.19$ \\
\hline \multirow[t]{2}{*}{ Hematocrit (\%) } & Tharparkar & $31.66^{\mathrm{Bc}} \pm 0.05$ & $33.21^{\mathrm{Ab}} \pm 0.18$ & $34.28^{\mathrm{Bb}} \pm 0.18$ & $36.31^{\mathrm{Ba}} \pm 0.32$ & $37.03^{\mathrm{Ba}} \pm 0.42$ \\
\hline & Karan Fries & $32.04^{\mathrm{Ae}} \pm 0.15$ & $33.93^{\mathrm{Bd}} \pm 0.25$ & $35.81^{A C} \pm 0.21$ & $37.8^{\mathrm{Ab}} \pm 0.24$ & $38.8^{\mathrm{Aa}} \pm 0.24$ \\
\hline \multirow[t]{2}{*}{ White blood cells $\left(\times 10^{3} / \mu \mathrm{l}\right)$} & Tharparkar & $13.44 \pm 0.38$ & $13.72 \pm 0.52$ & $13.74 \pm 0.72$ & $13.34 \pm 0.61$ & $13.88 \pm 0.73$ \\
\hline & Karan Fries & $12.97 \pm 0.58$ & $12.76 \pm 0.62$ & $12.94 \pm 0.35$ & $12.62 \pm 0.29$ & $13.2 \pm 0.40$ \\
\hline \multirow[t]{2}{*}{ Lymphocyte (\%) } & Tharparkar & $61.54 \pm 0.13$ & $61.06 \pm 0.15$ & $61.21 \pm 0.28$ & $61.28 \pm 0.30$ & $61.30 \pm 0.29$ \\
\hline & Karan Fries & $62.52 \pm 0.32$ & $62.42 \pm 0.22$ & $62.45 \pm 0.24$ & $62.79 \pm 0.40$ & $62.82 \pm 0.42$ \\
\hline \multirow[t]{2}{*}{ Granulocyte (\%) } & Tharparkar & $22.68 \pm 0.39$ & $23.46 \pm 1.10$ & $24.68 \pm 1.12$ & $25.82 \pm 1.13$ & $23.74 \pm 1.39$ \\
\hline & Karan Fries & $22.89 \pm 1.49$ & $22.18 \pm 1.26$ & $23.6 \pm 1.10$ & $25.86 \pm 1.37$ & $24.86 \pm 1.37$ \\
\hline \multirow[t]{2}{*}{ Monocyte (\%) } & Tharparkar & $13.16 \pm 1.57$ & $13.99 \pm 1.60$ & $14.68 \pm 1.18$ & $13.48 \pm 1.16$ & $12.56 \pm 1.76$ \\
\hline & Karan Fries & $14.73 \pm 1.25$ & $14.98 \pm 1.08$ & $15.54 \pm 0.30$ & $14.38 \pm 0.66$ & $12.94 \pm 0.66$ \\
\hline
\end{tabular}

Mean with different superscripts ( $A$ and $B$ ) in column differs significantly between the breeds for respective parameter for each exposure condition. Mean with different superscripts ( $a, b, c, d$, and e) in the same row differ significantly for respective breed for each exposure condition

$40^{\circ} \mathrm{C}$ and 500 and $600 \mathrm{ppm} \mathrm{CO}_{2} ; 42^{\circ} \mathrm{C}$ and 500 and 600 ppm $\mathrm{CO}_{2}$ levels.

Lateef et al. [25] reported the higher mean value of TEC in Kankrej cattle during hot summer. The authors suggested that the increase in RBC counts might be due to hemoconcentration during stressful condition and also due to higher PCV. In this study, hypercapnia (elevated level of $\mathrm{CO}_{2}$ ) resulted in increase of $\mathrm{RBC}$ counts is in support of Abdelatif et al. [26] who reported increase in $\mathrm{RBC}$ count and attributed that the increase in $\mathrm{RBC}$ count might be due to hypoxia-dependent upregulation of erythropoietin and also due to age, temperature, and seasonal conditions.

Shandya et al. [27] reported that heat stress caused an increase in PCV in buffaloes and attributed it to the loss of water from body due to dehydration. Similar observations were recorded by Omran et al. [28]. The author suggested that, when animals were exposed to high ambient temperatures, hemoconcentration developed due to dehydration, asphyxia, or excitement, which caused the release of erythrocytes from spleen, and thereby resulted in abnormally higher PCV levels. The higher PCV values might have caused due to increase in $\mathrm{RBC}$ and $\mathrm{Hb}$ concentration. At a higher level of $\mathrm{CO}_{2}$, there was a significant increase in $\mathrm{Hb}$ concentration in both Tharparkar and KF breeds of cattle.

The mean values of TLC, lymphocyte, granulocyte, and monocyte of Tharparkar and KF heifers during control and different exposure conditions are given in Table-2. In this study, it was observed that there was no significant difference in the TLC, lymphocyte, granulocyte, and monocyte count in both breeds at different temperatures and $\mathrm{CO}_{2}$ levels compared to control conditions. Similar results were reported in calves [29]. In both, the breeds, the leukocyte concentrations at $25^{\circ} \mathrm{C}, 400 \mathrm{ppm} \mathrm{CO}_{2} ; 40^{\circ} \mathrm{C}$,
500 and $600 \mathrm{ppm} \mathrm{CO}_{2}$; and $42^{\circ} \mathrm{C}, 500$ and $600 \mathrm{ppm}$ $\mathrm{CO}_{2}$ levels were non-significant statistically. Haque et al. [30] observed no change in granulocytes in young and adult Murrah buffaloes when they were exposed at $40^{\circ} \mathrm{C}, 42^{\circ} \mathrm{C}$, and $45^{\circ} \mathrm{C}$ in climatic chamber for $4 \mathrm{~h}$. Mirzadeh et al. [31] also reported lower levels of white blood cell in different breeds of cattle during summer than spring.

\section{Blood gases}

The values of blood $\mathrm{pH}, \mathrm{PCO}_{2}$, and $\mathrm{PO}_{2}$ in Tharparkar and KF heifers are given in Table-3. The blood $\mathrm{pH}$ and $\mathrm{PO}_{2}$ increased with increase in temperature and $\mathrm{CO}_{2}$ levels in both breeds, whereas the $\mathrm{PCO}_{2}$ decreased with the increase in temperature and $\mathrm{CO}_{2}$ levels and were significantly different in different exposure conditions in both Tharparkar and $\mathrm{KF}$ heifers. Between breeds, the values of blood $\mathrm{pH}$ were observed significantly $(\mathrm{p}<0.05)$ difference only at $42^{\circ} \mathrm{C}$ and $600 \mathrm{ppm} \mathrm{CO}_{2}$ level and $\mathrm{PCO}_{2}$ were significantly lower in KF than Tharparkar heifers at all exposure conditions, whereas the levels of $\mathrm{PO}_{2}$ were non-significant statistically at all exposure conditions.

The observation of blood $\mathrm{pH}$ is in accordance with the findings of Schneider et al. [32] who reported that cow subjected to heat stress had higher blood $\mathrm{pH}$ during hot hours compared to thermoneutral environment. Sivakumar et al. [33] reported increased $\mathrm{pH}$ level in goats under heat stress. Kadzere et al. [7] reported that $\mathrm{PCO}_{2}>40 \mathrm{~mm} \mathrm{Hg}$ stimulates RR, whereas lower $\mathrm{PCO}_{2}$ inhibits it. Helal et al. [34] found that increasing the concentration of inhaled $\mathrm{CO}_{2}$ by breathing is associated with hyperventilation and decrease in blood $\mathrm{PCO}_{2}$. The decrease in blood $\mathrm{PCO}_{2}$ is due to thermally induced hyperventilation which is similar to the finding of Sivakumar et al. [33].

The findings of $\mathrm{PO}_{2}$ in the present study are in accordance with the findings of Hales and Findley [35] 
Table-3: Effect of elevated temperature and $\mathrm{CO}_{2}$ levels in on blood $\mathrm{pH}$ and blood gases of Tharparkar and Karan Fries heifers.

\begin{tabular}{|c|c|c|c|c|c|c|}
\hline \multirow[t]{3}{*}{ Parameters } & \multirow[t]{3}{*}{ Breed } & \multirow{3}{*}{$\frac{\frac{25^{\circ} \mathrm{C}(\text { control })}{\mathrm{CO}_{2} \text { levels }(\mathrm{ppm})}}{400}$} & \multirow{2}{*}{\multicolumn{2}{|c|}{$\begin{array}{c}40^{\circ} \mathrm{C} \\
\mathrm{CO}_{2} \text { levels }(\mathrm{ppm})\end{array}$}} & \multirow{2}{*}{\multicolumn{2}{|c|}{$\begin{array}{c}42^{\circ} \mathrm{C} \\
\mathrm{CO}_{2} \text { levels }(\mathrm{ppm})\end{array}$}} \\
\hline & & & & & & \\
\hline & & & 500 & 600 & 500 & 600 \\
\hline \multirow[t]{2}{*}{$\mathrm{pH}$} & Tharparkar & $7.33^{\mathrm{Ae}} \pm 0.01$ & $7.36^{\mathrm{Ad}} \pm 0.005$ & $7.39^{\mathrm{AC}} \pm 0.005$ & $7.42^{\mathrm{Ab}} \pm 0.004$ & $7.45^{\mathrm{Ba}} \pm 0.005$ \\
\hline & Karan Fries & $7.32^{\mathrm{Ae}} \pm 0.01$ & $7.37^{\mathrm{Ad}} \pm 0.005$ & $7.40^{\mathrm{AC}} \pm 0.004$ & $7.44^{\mathrm{Ab}} \pm 0.003$ & $7.47^{\mathrm{Aa}} \pm 0.003$ \\
\hline \multirow[t]{2}{*}{$\mathrm{PCO}_{2}(\mathrm{mmHg})$} & Tharparkar & $55.03^{\mathrm{Aa}} \pm 0.22$ & $53.16^{\mathrm{Ab}} \pm 0.07$ & $50.83^{A C} \pm 0.25$ & $46.21^{\mathrm{Ad}} \pm 0.13$ & $42.13^{\mathrm{Ae}} \pm 0.22$ \\
\hline & Karan Fries & $54.31^{\mathrm{Aa}} \pm 0.27$ & $51.3^{\mathrm{Bb}} \pm 0.34$ & $48.11^{\mathrm{BC}} \pm 0.26$ & $43.36^{\mathrm{Bd}} \pm 0.28$ & $39.75^{\mathrm{Be}} \pm 0.19$ \\
\hline \multirow[t]{2}{*}{$\mathrm{PO}_{2}(\mathrm{mmHg})$} & Tharparkar & $41.88^{\mathrm{Ad}} \pm 0.57$ & $46.78^{A C} \pm 0.63$ & $48.81^{\mathrm{Abc}} \pm 0.57$ & $51.31^{\mathrm{Aba}} \pm 0.65$ & $53.33^{\mathrm{Aa}} \pm 0.63$ \\
\hline & Karan Fries & $40.50^{\mathrm{Be}} \pm 0.12$ & $46.36^{\mathrm{Ad}} \pm 0.33$ & $48.4^{A C} \pm 0.33$ & $50.41^{\mathrm{Ab}} \pm 0.46$ & $54.38^{\mathrm{Aa}} \pm 0.26$ \\
\hline
\end{tabular}

Mean with different superscripts ( $A$ and $B$ ) in column differs significantly between the breeds for respective parameter for each exposure condition. Mean with different superscripts ( $a, b, c, d$, and e) in the same row differ significantly for respective breed for each exposure condition

who reported that heat stress raised the $\mathrm{PO}_{2}$ and the increase was attributed to increase in alveolar ventilation. Wojtas et al. [36] also reported an increased level of $\mathrm{PO}_{2}$ in Polish Merino sheep when expose to high temperature $\left(30^{\circ} \mathrm{C}\right)$. The increase in $\mathrm{PO}_{2}$ in the present study due to elevated $\mathrm{CO}_{2}$ levels is in accordance with the findings of Sabuncuoglu et al. [6] who reported that in cattle blood $\mathrm{PO}_{2}$ increased by higher temperature, higher $\mathrm{CO}_{2}$ level, and $\mathrm{RH}$ in cattle.

BE

The value of blood BE was significantly $(P<0.01)$ lower during different exposure conditions compared to control conditions in both Tharparkar and KF heifers (Figure-1).

The findings are in accordance with the result of Srikandakumar et al. [37] who reported a decrease in $\mathrm{BE}$ in sheep when subjected to heat stress. A similar finding was reported by Hussein and Aamer [38] in ovine. The probable reason of reduction in $\mathrm{BE}$ might be due to low oxygen tension $\left(\mathrm{PO}_{2}\right)$ which might have increased anaerobic glycolysis to cause excess production of lactic acid. Korde et al. [39] also reported low BE in buffalo calves in heat stress condition and suggested that it might be a compensatory response to respiratory alkalosis. West et al. [40] also observed low BE in heat-stressed dairy cows and suggested that the reduction in $\mathrm{BE}$ might be due to either increased respiratory rate/panting under heat stress, which eliminated $\mathrm{CO}_{2}$ in excess and caused decreased $\mathrm{PCO}_{2}$ as well as carbonic acid, or it might be due to decrease in the non-bicarbonate buffer system, particularly $\mathrm{Hb}$ which resulted in decreased levels of buffer in blood.

\section{Animal behavior}

The parameters of physiological behavior in Tharparkar and KF are given in Table-4. During control conditions, both the breeds of cattle were calm and quiet with all the physiological parameters in the normal range. During exposure, there were significant $(p<0.05)$ changes in behavioral parameters of both breeds as given in Table-4. Moreover, changes were more apparent in KF compare to Tharparkar.

Behavior of both the breeds changed with changes in temperature and $\mathrm{CO}_{2}$ levels. Animals of

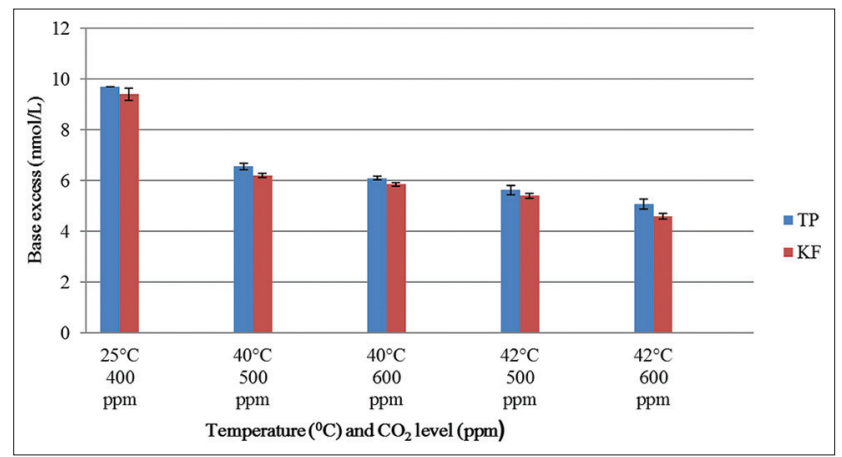

Figure-1: Effect of elevated temperature and $\mathrm{CO}_{2}$ levels on the base excess of Tharparkar and Karan Fries heifers.

both breeds were more nervous and restlessness, and there was increased salivation, profuse tongue protrusion, and panting. Panting was observed when the normal heat dissipation mechanism was compromised, and it culminated into evaporative cooling as the most effective means of heat loss. All the physiological parameters increased compared to control conditions. Both the breeds spent most of the time in standing with the increase in stress level due to increased temperature and $\mathrm{CO}_{2}$ levels. Water consumption increased in both the breeds. The changes were higher in KF than Tharparkar heifers indicating that KF were more susceptible to heat stress. Nardone et al. [41] reported increased panting, lowered saliva production, and decreased rumination during thermal stress in livestock. One of the changes associated with behavior during heat load is an increase in time spent in standing [42]. Cattle may reduce the effects of high heat load by increasing water consumption. Access to cool drinking water improved weight gain in feedlot cattle in summer [43]. The behavioral changes help in the acclimatization process of animals during a stressful period and can be used to assess the impact of thermal stress in ruminants.

\section{Conclusion}

On the basis of this study, it can be concluded that the fluctuations in physiological responses, blood constituents, and behavioral changes during heat stress and hypercapnia are an effort to maintain 
Table-4: Effect of elevated temperature and $\mathrm{CO}_{2}$ levels on behavior of Tharparkar and Karan Fries heifers.

\begin{tabular}{|c|c|c|c|c|c|c|}
\hline \multirow[t]{3}{*}{ Parameter } & \multirow[t]{3}{*}{ Breed } & \multirow{3}{*}{$\begin{array}{l}\frac{25^{\circ} \mathrm{C} \text { (control) }}{\mathrm{CO}_{2} \text { levels }(\mathrm{ppm})} \\
400\end{array}$} & \multirow{2}{*}{\multicolumn{2}{|c|}{$\begin{array}{l}40^{\circ} \mathrm{C} \\
\mathrm{CO}_{2} \text { levels }(\mathrm{ppm})\end{array}$}} & \multirow{2}{*}{\multicolumn{2}{|c|}{$\begin{array}{l}42^{\circ} \mathrm{C} \\
\mathrm{CO}_{2} \text { levels }(\mathrm{ppm})\end{array}$}} \\
\hline & & & & & & \\
\hline & & & 500 & 600 & 500 & 600 \\
\hline \multirow[t]{2}{*}{ Restlessness } & Tharparkar & Calm and quiet & Disturbed & Bad temperament & Excited & Furious \\
\hline & Karan Fries & Calm and quiet & More disturbed & Bad temperament & Highly excited & More furious \\
\hline \multirow{2}{*}{$\begin{array}{l}\text { Open mouth } \\
\text { panting }\end{array}$} & Tharparkar & Absent & High & High & Higher & Higher \\
\hline & Karan Fries & Absent & Higher & Higher & Highest & Highest \\
\hline \multirow[t]{2}{*}{$\begin{array}{l}\text { Tongue } \\
\text { protrusion }\end{array}$} & Tharparkar & Absent & $\begin{array}{l}\text { Occasional } \\
\text { mouth opening }\end{array}$ & $\begin{array}{l}\text { Frequent } \\
\text { appearance of } \\
\text { tongue }\end{array}$ & $\begin{array}{l}\text { Continuous } \\
\text { protrusion }\end{array}$ & $\begin{array}{l}\text { Continuous } \\
\text { protrusion }\end{array}$ \\
\hline & Karan Fries & Absent & $\begin{array}{l}\text { Frequent } \\
\text { appearance of } \\
\text { tongue }\end{array}$ & $\begin{array}{l}\text { Continuous } \\
\text { protrusion }\end{array}$ & Tongue fully out & Tongue fully out \\
\hline \multirow[t]{2}{*}{ Frothy salivation } & Tharparkar & Absent & $\begin{array}{l}\text { Dribbling of } \\
\text { saliva starts }\end{array}$ & $\begin{array}{l}\text { Continuous } \\
\text { dribbling }\end{array}$ & $\begin{array}{l}\text { Appearance of } \\
\text { froth on upper lip }\end{array}$ & $\begin{array}{l}\text { Full mouth } \\
\text { frothing }\end{array}$ \\
\hline & Karan Fries & Absent & $\begin{array}{l}\text { Dribbling of } \\
\text { saliva starts }\end{array}$ & $\begin{array}{l}\text { Continuous } \\
\text { dribbling }\end{array}$ & $\begin{array}{l}\text { Appearance of } \\
\text { froth on upper lip }\end{array}$ & $\begin{array}{l}\text { Full mouth } \\
\text { frothing }\end{array}$ \\
\hline \multirow[t]{2}{*}{ Muzzle secretion } & Tharparkar & Absent & High & High & Higher & Higher \\
\hline & Karan Fries & Absent & Higher & Higher & Highest & Highest \\
\hline \multirow[t]{2}{*}{ Standing time } & Tharparkar & Less & Increased & Increased & Highly increased & Highly increased \\
\hline & Karan Fries & Less & Increased & Increased & Highly increased & Highly increased \\
\hline
\end{tabular}

normal homeostasis of the body and can be used as an index for assessing the adaptation capacity of cattle to changing climate that helps in the acclimatization process of animals during stressful period and can be used to assess the impact of thermal and $\mathrm{CO}_{2}$ stress in ruminants.

\section{Authors' Contributions}

$\mathrm{OKH}$ designed the study. PP conducted the experiment. PP and SK performed statistical analysis. PP and SK drafted and revised the manuscript under the guidance of OKH. All authors read and approved the final manuscript.

\section{Acknowledgments}

The authors express sincere thanks to the Director, ICAR-NDRI, Karnal, for providing all necessary facilities for conducting research work. The authors also acknowledge PI, NICRA project no.30033 for financial help to carry out this research work.

\section{Competing Interests} interest.

The authors declare that they have no competing

\section{References}

1. IPCC. (2007) The Intergovernmental Panel on Climate Change $4^{\text {th }}$ Assessment Report. Available from: http://www. Ipcc.ch/publicationsanddata/publicationsanddatareports. Htm\#2. Last accessed on 07-04-2017.

2. Ahmed, A., Tiwari, R.P., Mishra, G.K., Jena, B., Dar, M.A and Bhat, A.A. (2015) Effect of environmental heat stress on reproduction performance of dairy cows-a review. Int. $J$. Livest. Res., 5(4): 10-18.

3. McManus, C., Paludo, G.R., Louvandini, H., Gugel, R., Sasaki, L.C.B. and Paiva, S.R. (2009) Heat tolerance in Brazilian sheep: Physiological and blood parameters. Trop. Anim. Health. Prod., 41(1): 95-101.
4. Maibam, U., Hooda, O.K., Sharma, P.S., Singh, S.V., Mohanty, A.K. and Upadhyay, R.C. (2017) Seasonal variation in HSP70 expression and oxidative stress in skin of zebu (Tharparkar) and crossbred (Karan Fries) cattle under tropical climate. Biol. Rhythm. Res., 48: 1-15.

5. Bhan, C., Singh, S.V., Hooda, O.K., Upadhyay, R.C. and Beenam, B. (2013) Influence of temperature variability on physiological, haematological and biochemical profiles of growing and adult Karan Fries cattle. Indian J. Anim. Sci., 83(10): 1090-1096.

6. Sabuncuoglu, N., Coban, O., Lacin, E., Yildiz, A., Akbulut, O., Yaganoglu, A.V. and Sagsoz, Y. (2007) Effect of barn ventilation on blood gas status and some physiological traits of dairy cows. J. Environ. Biol., 29(1): 107.

7. Kadzere, C.T., Murphy, M.R., Silanikove, N. and Maltz, E. (2002) Heat stress in lactating dairy cows: A review. Livest. Prod. Sci., 77: 59-91.

8. Hayashi, K., Honda, Y., Miyakawa, N., Fujii, N., Ichinose, M., Koga, S. and Nishiyasu, T. (2011) Effect of $\mathrm{CO} 2$ on the ventilatory sensitivity to rising body temperature during exercise. J. Appl. Physiol., 110(5): 1334-1341.

9. SAS, Institute. (2011) Statistical Analysis System, Version 9.1. SAS Institute, Cary, NC, USA.

10. Kumar, S., Singh, S.V. and Soren, S. (2017) Physiological responses and in-vitro volatile fatty acid production in cattle. Int. J. Curr. Microbiol. Appl. Sci., 6(2): 86-94.

11. Davinder, K. (2011) Effect of Oxygen Rich Air on Different Physiological and Biochemical Parameters in Cattle and Buffaloes During Extreme Hot and Cold Environment (Master's Thesis). National Dairy Research Institute, Karnal Haryana.

12. Indu, B. (2014) Expression of HSP 27, 90 and 105 Genes in Peripheral Blood Mononuclear Cells During Thermal Stress in Tharparkar and Karan Fries Cross Bred Cattle (Master's Thesis). National Dairy Research Institute, Karnal Haryana.

13. Das, R., Sailo, L., Verma, N., Bharti, P., Saikia, J., Imtiwati. and Kumar, R. (2016) Impact of heat stress on health and performance of dairy animals: A review. Vet. World, 9(3): 260-268.

14. Singh, S.V. and Upadhyay, R.C. (2009) Impact of temperature rise on physiological function, thermal balance and milk production of lactating Karan fries and Sahiwal cows. Indian Vet. J., 86: 141-144.

15. Hooda, O.K. and Upadhyay, R.C. (2015) Growth rate, 
hormonal and physiological responses of kids subjected to thermal and exercise stress. J. Environ. Res. Develop., 9(4): 1095-1101.

16. Mohr, E., Langbein, J. and Nurnberg, G. (2002) Heart rate variability: A non-invasive approach to measure stress in calves and cows. Physiol. Behav., 75: 251-259.

17. Sagsoz, Y., Tuzemen, N., Yanar, M., Akbulut, O.M.E. and Aydin, R.E.C. (2003) Effect of different housing conditions on the milk production and some physiological characteristics of Holstein Friesian cows. Indian J. Anim. Sci., 73: 104-106.

18. Gaughan, J.B., Mader, T.L., Holt, S.M., Josey, M.J. and Rowan, K.J. (1999) Heat tolerance of Boran and Tuli crossbred steers. J. Anim. Sci., 77: 2398-2405.

19. Aggarwal, A. and Upadhyay, R.C. (1997) Pulmonary and skin evaporative heat loss during exercise in hot dry conditiond in crossbreds. Indian J. Anim. Sci., 67: 51-53.

20. Silanikove, N. (2000) Effects of heat stress on the welfare of extensively managed domestic ruminants. Livest. Prod. Sci., 67: 1-18.

21. Moran, J.B. (1999) Heat tolerance of Brahman cross, buffalo, banteny and shorthorn steers during exposure to sun and as a result of exercise. Aust. J. Agric. Res., 24: 775-782.

22. Chandra, B., Singh, S.V., Hooda, O.K., Upadhyay, R.C., Beenam, B. and Vaidya, M. (2012) Influence of temperature variability on physiological, hematological and biochemical profile of growing and adult Sahiwal cattle. J. Environ. Res. Dev., 7(2A): 986-994.

23. Randhawa, S.S., Chhabra, S., Randhawa, C.S., Zahid, U. and Dhaliwal, P.S. (2014) A note on treatment of hyperthermia in crossbred cattle. Asian Pac. J. Trop. Med., 4: $272-274$.

24. Hansen, P.J. (2004) Physiological and cellular adaptation of Zebu cattle to thermal stress. Ani. Rep. Sci., 82-83: 349-360.

25. Lateef, A., Das, H., Panchasara, H.H., Nilufar, H. and Sanap, M.J. (2014) Seasonal effects on milk yield, erythrocytic and leukocytic indices of Kankrej cattle (Bos indicus). Vet. World, 7: 472-477.

26. Abdelatif, A.M., Ibrahim, M.Y. and Hassan, Y.Y. (2009) Seasonal variation in erythrocytic and leukocytic indices and serum proteins of female Nubian goats middle-East. J. Sci. Res., 4(3): 168.

27. Shandya, S., Singh, V.K., Upadhyay, R.C., Puri, G., Odedara, A.B. and Patel, P.A. (2015) Evaluation of physiological and biochemical responses in different seasons in Surti buffaloes. Vet. World, 8(6): 727-731.

28. Omran, F.I., Ashour, G.H., Hassan, L.R., Shafie, M.M. and Youssef, M.M. (2011) Physiological responses and growth performance of buffalo and Friesian calves under chronic severe heat stress. In: Proceedings of the $4^{\text {th }}$ Scientific Conference of Animal Wealth Research in the Middle East and North Africa, Foreign Agricultural Relations (FAR). Massive Conferences and Trade Fairs, Egypt. p1-13.

29. Broucek, J., Kisac, P. and Uhrincat, M. (2009) Effect of hot temperature on the hematological parameters, health and performance of calves. Int. J. Biometeorol., 53: 201-208.

30. Haque, N., Ludri, A., Hossain, S.A. and Ashutosh, M. (2013) Impact on hematological parameters in young and adult Murrah buffaloes exposed to acute heat stress. Art. Buffalo Bull., 32(2): 321-326.

31. Mirzadeh, K.H., Tabatabaei, S., Bojarpour, M. and Mamoei, M. (2010) Comparative study of hematological parameters according strain, age, sex, physiological status and season in Iranian cattle. Asian J. Anim. Vet. Adv., 16: 2123-2127.

32. Schneider, P.L., Beede, D.K. and Wilcox, C.J. (1988) Nycterohemeral patterns of acid-base status, mineral concentrations and digestive function of lactating cows in natural or chamber heat stress environments. J. Anim. Sci., 66: $112-125$.

33. Sivakumar, A.V.N., Singh, G. and Varshney, V.P. (2010) Antioxidant supplementation on acid base balance during heat stress in goats. Asian Aust. J. Anim. Sci., 23: 1462-1468.

34. Helal, A., Hashem, A.L.S., Abdel-Fattah, M.S. and El-Shaer, H.M. (2010) Effect of heat stress on coat characteristics and physiological responses of Balady and Damascus goats in Sinai, Egypt. Am. Euresian J. Agric. Environ. Sci., 7(1): 60-69.

35. Hales, J.R.S. and Findlay, J.D. (1968) The oxygen cost of thermally induced and $\mathrm{CO}$ induced hyperventilation in the ox. Respir. Physiol., 4: 353-356.

36. Wojtas, K., Cwynar, P., Kolacz, R. and Kupczynski, R. (2013) Effect of heat stress on acid-base balance in Polish Merino Sheep. Arch. Tierzucht, 56: 917-923.

37. Srikandakumar, A., Johnson, E.H. and Mahgoub, O. (2003) Effect of heat stress on respiratory rate, rectal temperature and blood chemistry in Omani and Australian Merino Sheep. Small Rum. Res., 49: 193-198.

38. Hussein, H.A. and Aamer, A.A. (2013) Influence of different storage times and temperature on blood gas and acidbase balance in ovine venous blood. Open Vet. J., 3: 1-7.

39. Korde, J.P., Singh, G., Varshney, V.P. and Shukla, D.C. (2007) Effects of long-term heat exposure on adaptive mechanism of blood acid-base in buffalo-calves. Asian Aust. J. Anim. Sci., 13: 329-332.

40. West, J.W., Mullinix, B.G. and Sandifer, T.G. (1991) Changing dietary electrolytes balance for dairy cows in cool and hot environments. J. Dairy Sci., 74: 1662-1674.

41. Nardone, A., Ronchi, B., Lacetera, N., Ranieri, M.S. and Bernabucci, U. (2010) Effects of climate changes on animal production and sustainability of livestock systems. Livest. Sci., 130(1): 57-69.

42. Overton, M.W., Sischo, W.M., Temple, G.D. and Moore, D.A. (2002) Using time-lapse video photography to assess dairy cattle lying behavior in a free-stall barn. $J$. Dairy Sci., 85(9): 2407-2413.

43. Ittner, N.R., Kelly, C.F. and Guilbert, H.R. (1951) Water consumption of Hereford and Brahman cattle and the effect of cooled drinking water in a hot climate. J. Anim. Sci., 10(3): 742-751. 